\title{
The Characteristics and Safety of Previous Fillers in Secondary Rhinoplasty
}

\author{
Bong Il Rho ${ }^{1}$, Seok Min Yoon ${ }^{2}$, \\ Eun Soo Park ${ }^{3}$, Syeo Young Wee ${ }^{2}$ \\ ${ }^{1}$ Glovi Plastic Clinic, Seoul; ${ }^{2}$ Department \\ of Plastic and Reconstructive Surgery, \\ Soonchunhyang Gumi Hospital, \\ Soonchunhyang University College of \\ Medicine, Gumi; ${ }^{3}$ Department of Plastic \\ and Reconstructive Surgery, \\ Soonchunhyang Bucheon Hospital, \\ Soonchunhyang University College of \\ Medicine, Bucheon, Korea
}

This work was supported in part by the Soonchunhyang University Research Fund.

No potential conflict of interest relevant to this article was reported.

\begin{abstract}
Background Filler injection into the soft tissue of the nose is a useful technique for rhinoplasty. The individual characteristics of fillers determine which is best suited for a patient's specific circumstances. The objective of this study was to identify the characteristics of various fillers and to determine which fillers should be used for primary rhinoplasty in order to yield optimal long-term results.

Methods Excluding patients treated with hyaluronic acid fillers, we reviewed 17 patients who underwent surgical rhinoplasty due to dissatisfaction with an injection using a different filler. After removing the previously injected filler, rhinoplasty was performed as part of the same procedure using a silicone or Surgiform ${ }^{\oplus}$ prosthesis.

Results Various previous fillers were used in the cohort. During the process of filler removal, skin perforation occurred in 2 cases and infection was observed in 1 case. In the other cases, rhinoplasty using a prosthesis was performed at the time of filler removal and no complications were observed.

Conclusions We found that if surrounding tissue had been maintained stably, a simultaneous secondary operation using implants produced ideal results in most cases without any complications, despite the presence of residual remnant filler material.
\end{abstract}

Keywords Dermal fllers, Rhinoplasty, Silicones

\section{INTRODUCTION}

Filler injection into the soft tissue of the nose is a useful method for rhinoplasty. Soft-tissue fillers have become more prevalent for facial augmentation in the last 2 decades, even though the complications of permanent fillers can be challenging to treat [1]. Recently, various soft-tissue fillers have become available. Each filler has its own properties, so the clinician must choose the proper filler according to the patient's needs to obtain good aesthetic results and to prevent undesired complications [2]. Many types of filler prod-

Received: Jan 29, 2018 Revised: Apr 4, 2018 Accepted: Apr 11, 2018 Correspondence: Syeo Young Wee Department of Plastic and Reconstructive Surgery, Soonchunhyang Gumi Hospital, Soonchunhyang University College of Medicine, 1791 gongdan-ro, Gumi 39371, Korea. E-mail:94061@schmc.ac.kr

Copyright $\odot 2018$ The Korean Society for Aesthetic Plastic Surgery.

This is an Open Access article distributed under the terms of the Creative Commons Attribution Non-Commercial License (http://creativecommons.org/licenses/by-nc/4.0/) which permits unrestricted non-commercial use, distribution, and reproduction in any medium, provided the original work is properly cited. $\quad w w w . e-a a p s . o r g$ ucts have been used to reconstruct nasal deformities and to supplement rhinoplasty, especially for nasal dorsal augmentation.

The use of fillers for reinforcement after primary rhinoplasty using implant material is common. In such procedures, the choice of filler depends on the characteristics of the filler and the requirements of the case. However, little information is available on the use of fillers for primary rhinoplasty. Consequently, insufficient studies have investigated open rhinoplasty as a secondary operation after primary rhinoplasty with filler. Moreover, no retrospective study has been performed to determine the later effects and features of existing fillers.

We evaluated patients who had undergone nasal dorsal augmentation with a filler. Open rhinoplasty was performed as a secondary operation. In this process, we evaluated the ease of removal of the previously injected filler, the characteristics of the removed filler, and the viability of the surrounding tissues.

The objectives of this study were to identify the characteristics of the fillers used for the primary operations and to determine which filler produced better long-term results. 


\section{METHODS}

We retrospectively reviewed 17 patients who visited our hospital for secondary rhinoplasty from 2009 to 2012, and investigated how the primary filler type affected the secondary operation. Patients who had been injected with hyaluronic acid (HA) fillers were excluded.

Patients visited our hospital because there had been changes in the contour of the nasal soft tissue over time, resulting in cosmetic dissatisfaction. Secondary operations were performed by open rhinoplasty under local anesthesia from several months to several years after the first operation. In the open approach, the previously injected fillers were carefully removed to minimize injury to the surrounding tissues, and sufficient irrigation was performed. The appearance of the previously injected filler was assessed. Preoperative and postoperative photographs were compared and it was determined whether aesthetic improvements had taken place.
Rhinoplasty was performed at the time of primary filler removal, using a silicone or Surgiform ${ }^{\circledR}$ (Surgiform Technology, Ltd., Lugoff, SC, USA) prosthesis.

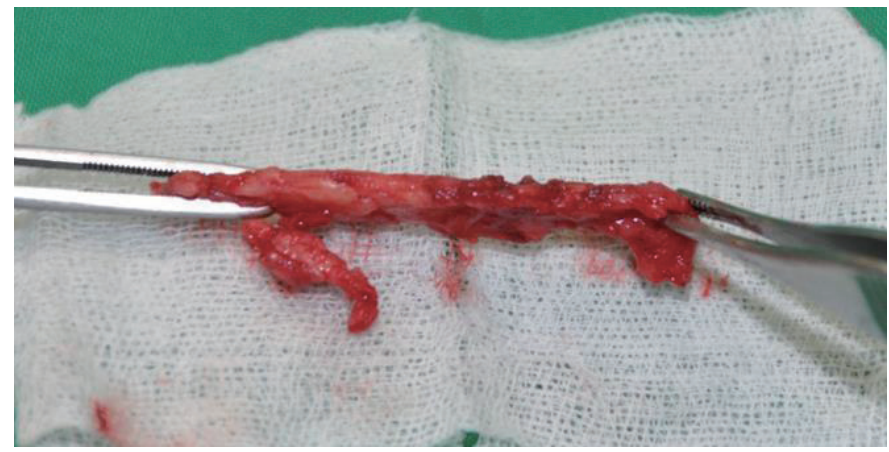

Fig. 1. Morphologic features of Artecoll ${ }^{\circledast}$. Artecoll ${ }^{\circledR}$ was clustered together, forming a lumpy shape like that of an implant.

Table 1. Characteristics of previously injected fillers

\begin{tabular}{|c|c|c|c|c|}
\hline Brand name & Main components & Duration of results & No. of cases & Features when removed \\
\hline Aquamid $^{\circledR}$ & $97.5 \%$ sterile water, $2.5 \%$ polyacrylamide & At least 5 years & 4 & Encapsulated gel, easy to remove \\
\hline Bio-alcamid $^{\circledR}$ & $96.0 \%$ nonpyrogenic water, $4.0 \%$ alkylimide groups & At least 5 years & 3 & Encapsulated gel, easy to remove \\
\hline Artecoll $^{\circledR}$ & $\begin{array}{l}\text { Contains PMMA enclosed in a solution of } 3.5 \% \text { colla- } \\
\text { gen, } 0.3 \% \text { lidocaine }\end{array}$ & 1 year (but may be permanent) & 2 & $\begin{array}{l}\text { Solid, tissue tightly bonded to the ad- } \\
\text { jacent tissue, difficult to remove }\end{array}$ \\
\hline Lipen $^{\circledR}$ & $\begin{array}{l}75 \% \text { cross-linked dextran, 15\% PMMA, 10\% hyprom- } \\
\text { ellose solution }\end{array}$ & At least 5 years & 1 & $\begin{array}{l}\text { Solid, tissue tightly bonded to the ad- } \\
\text { jacent tissue, difficult to remove }\end{array}$ \\
\hline Radiesse $^{\circledR}$ & $\begin{array}{l}\text { Calcium hydroxyapatite microspheres suspended in a } \\
\text { carrier gel }\end{array}$ & $\begin{array}{l}\text { At least } 1 \text { year laverage 12-15 } \\
\text { months) }\end{array}$ & 7 & Powder, difficult to remove \\
\hline
\end{tabular}

PMMA, polymethyl methacrylate.
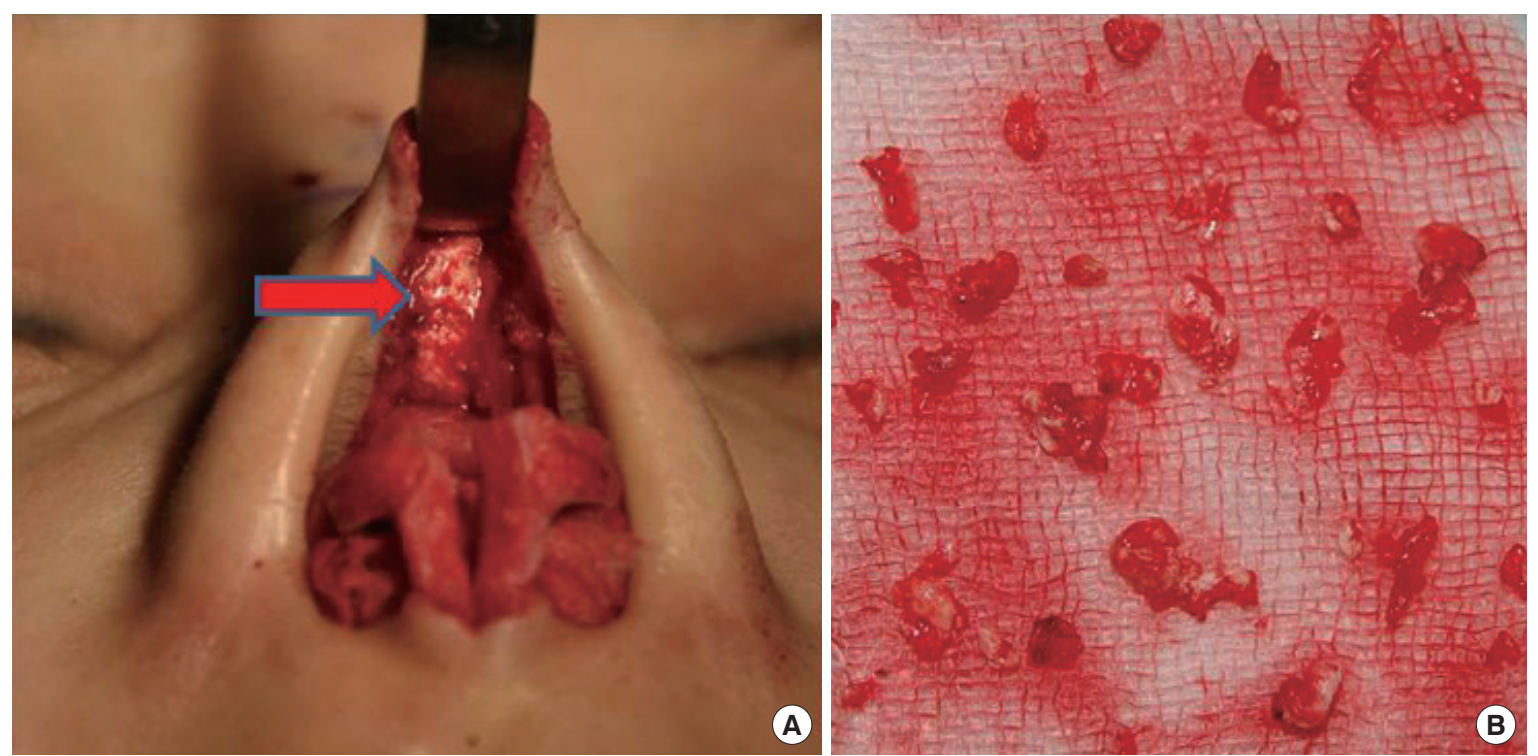

Fig. 2. Morphologic features of Radiesse ${ }^{\circledR}$. Radiesse ${ }^{\circledR}$ (arrow) had a particluate pattern and its powder components were embedded in the tissue. 


\section{RESULTS}

Various types of filler were used during the primary procedures at other clinics (Table 1). Artecoll ${ }^{\circledR}$ (Hafod Bioscience BV, Nijmegen, The Netherlands) produced lumpy shapes, and its adhesion to the skin made it difficult to remove (Fig. 1). The well-known semipermanent filler Radiesse ${ }^{\circledast}$ (BioForm Medical Inc., San Mateo, CA, USA) showed a particulate pattern and its powder components became embedded in the tissue, which made complete removal impossible (Fig. 2). Non-biodegradable products of the encapsulated gel type, such as Aquamid ${ }^{\circledR}$ (Ferrosan, Copenhagen, Denmark) and
Bio-Alcamid ${ }^{\boxplus}$ (Polymekon, Milan, Italy), were easier to remove than artecoll and radiesse (Fig. 3 and 4).

The filler was removed and silicone or Surgiform ${ }^{\circledR}$ implants were placed as a secondary operation. After the initial filler injections, the mean interval before patients visited our clinic to undergo the secondary operation was 8 months (Table 2). The photographic findings after the secondary operation confirmed that the causes of the patients' previous cosmetic dissatisfaction had been solved (Fig. 5).

During the process of filler removal, skin perforation occurred in 2 cases and infection was observed in 1 case. The case of infection involved a secondary operation using Surgiform ${ }^{\circledR}$ that was per-
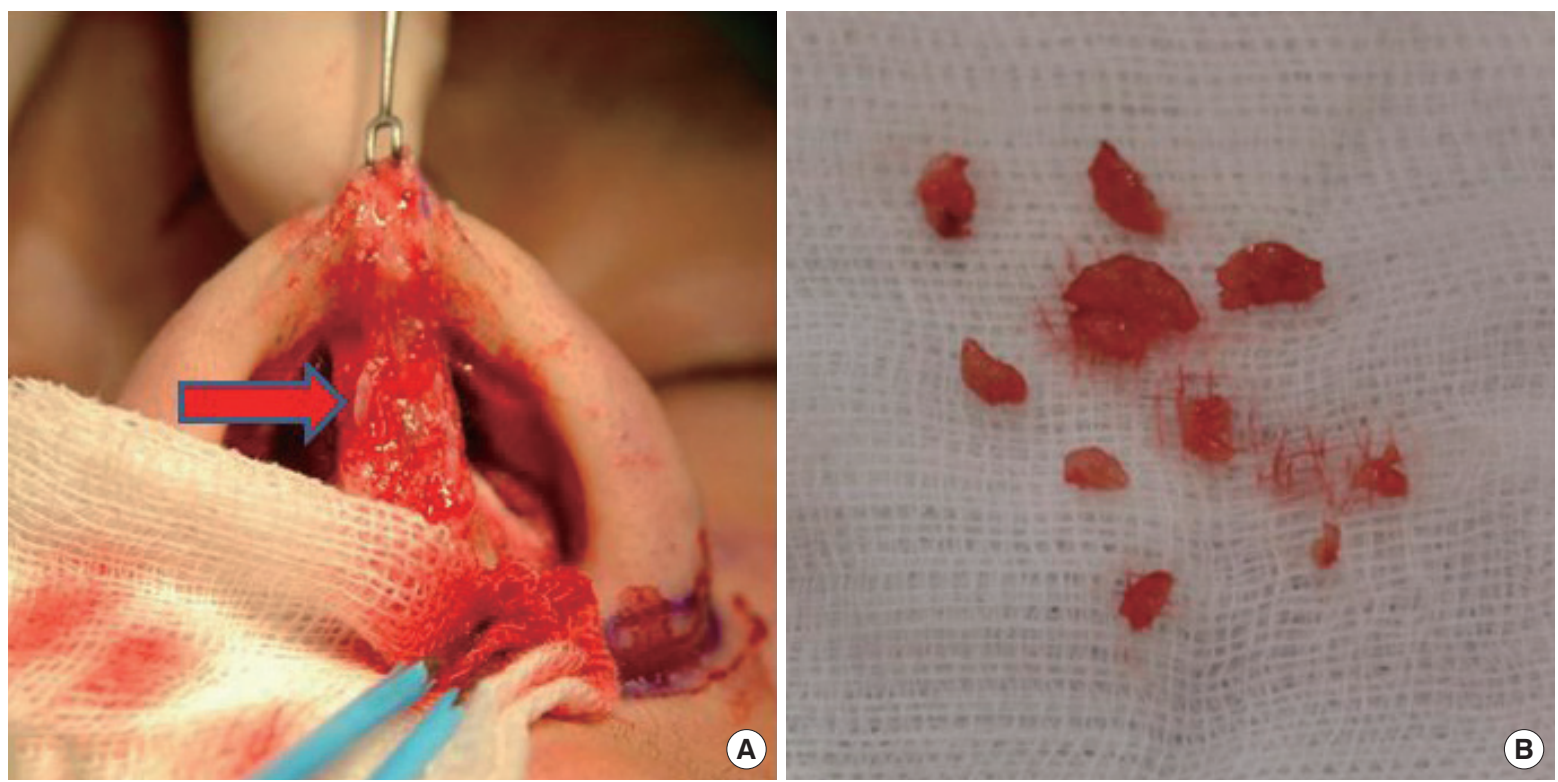

Fig. 3. Morphologic features of Aquamid ${ }^{\circledR}$. Aquamid ${ }^{\circledR}$ (arrow) was easier to remove than other materials due to being an encapsulated gel.
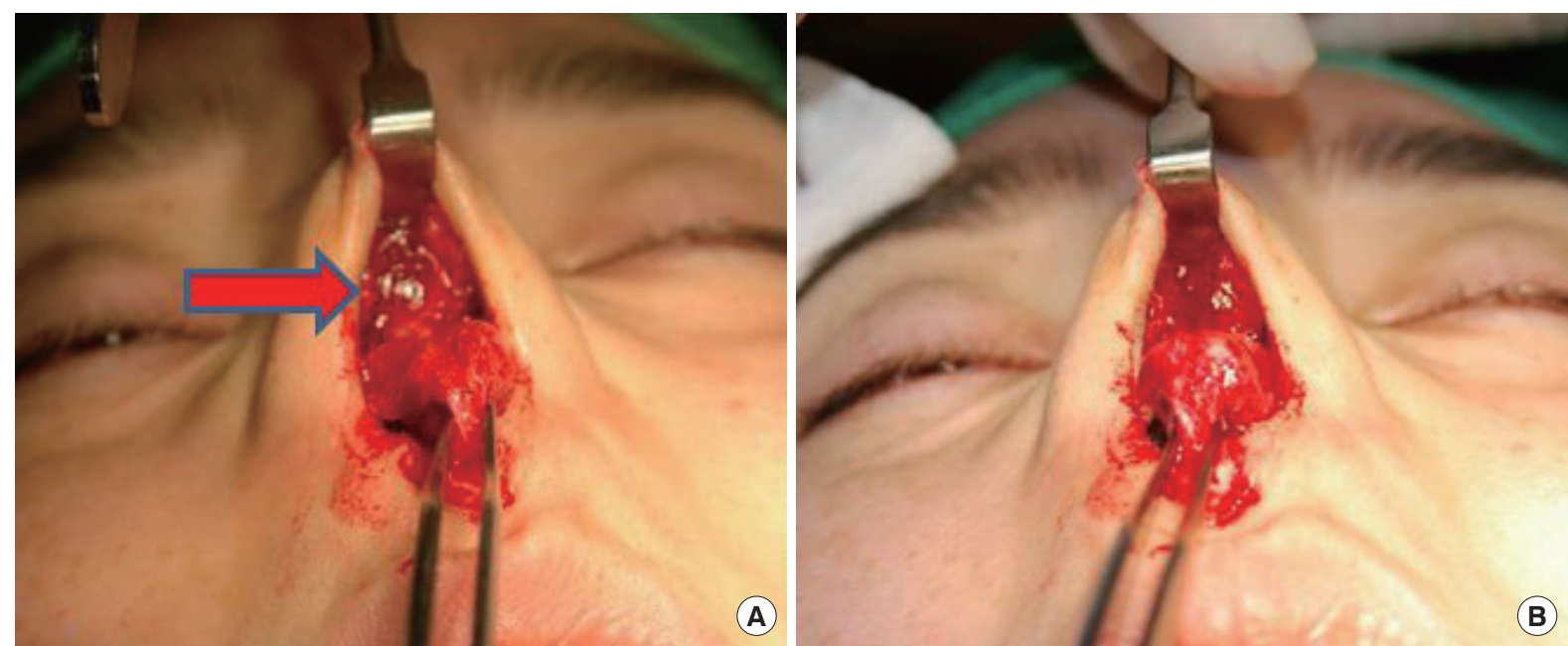

Fig. 4. Morphologic features of Bio-alcamid ${ }^{\circledR}$. Bio-alcamid ${ }^{\circledR}$ (arrow) was easier to remove than other materials due to being an encapsulated

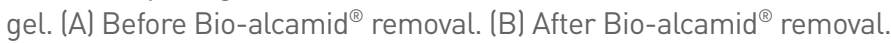


Table 2. Interval between the filler injection and the secondary operation, filler type, prosthetic materials used in the secondary operation, and complications

\begin{tabular}{|c|c|c|c|c|c|c|}
\hline Patient no. & Sex & $\begin{array}{c}\text { Age } \\
\text { (year) }\end{array}$ & $\begin{array}{l}\text { Interval from filler injection to } \\
\text { secondary operation (month) }\end{array}$ & Type of injected filler & Prosthetic material & Complications \\
\hline 1 & M & 23 & 8 & Aquamid $^{\circledR}$ & Silicone & No \\
\hline 3 & $\mathrm{~F}$ & 45 & 5 & Aquamid $^{\circledast}$ & Surgiform ${ }^{\circledast}$ & No \\
\hline 4 & $\mathrm{~F}$ & 43 & 10 & Aquamid $^{\circledR}$ & Surgiform ${ }^{\oplus} \rightarrow$ Silicone & Infection \\
\hline 7 & $\mathrm{~F}$ & 35 & 12 & Bio-alcamid $^{\circledR}$ & Surgiform ${ }^{\circledast}$ & No \\
\hline 8 & M & 29 & 8 & Artecoll ${ }^{\circledast}$ & Silicone & No \\
\hline 9 & M & 30 & 12 & Artecoll ${ }^{\circledast}$ & Silicone & Skin perforation \\
\hline 10 & $\mathrm{~F}$ & 33 & 10 & Lipen $^{\circledR}$ & Silicone & Skin perforation \\
\hline 14 & $\mathrm{~F}$ & 26 & 10 & Radiesse ${ }^{\circledast}$ & Silicone & No \\
\hline 15 & $\mathrm{~F}$ & 26 & 5 & Radiesse ${ }^{\circledR}$ & Silicone & No \\
\hline 16 & $\mathrm{~F}$ & 37 & 6 & Radiesse ${ }^{\circledast}$ & Silicone & No \\
\hline 17 & $\mathrm{~F}$ & 34 & 6 & Radiesse $^{\circledR}$ & Silicone & No \\
\hline
\end{tabular}

$M$, male; F, female.

formed after the removal of Aquamid ${ }^{\circledR}$. The Surgiform ${ }^{\circledR}$ was removed due to inflammation that occurred 10 months after the secondary operation, and silicone was inserted 17 months after removal of Surgiform ${ }^{\circledR}$. In one of the cases of skin perforations, Artecoll ${ }^{\circledR}$ had been injected, according to the patient. The previously injected filler was semipermanent, and the complication occurred during removal. In the other case, the patient had previously been injected with LiPen ${ }^{\circledR}$ (Chung Hwa MediPower Co. Ltd., Jangsung, Korea). Based on the appearance of the primary filler product, it was determined to be a polymethyl methacrylate (PMMA) product that adhered to the skin, which led to skin perforation. The perforation occurred at the supratip dorsum area and the left lateral wall of the dorsum. It was treated by primary closure and augmentation rhinoplasty using a prosthetic material. Because a depression remained in the supratip dorsum, dermal graft transplantation was conducted 6 months later. The lateral wall perforation was well treated. In the other 14 cases, rhinoplasty was performed using a prosthetic material at the time of filler removal, and no complications such as irregularity of the skin surface or implant protrusion were observed.

\section{DISCUSSION}

Various types of fillers have been widely used for rhinoplasty by plastic surgeons. Soft-tissue filler injection is commonly used to correct irregularities or asymmetries after rhinoplasty [3]. Filler injections can be attempted in patients who do not have an indica- tion for operation or require an interval before the second operation [3-5]. Fillers have the advantage of allowing the correction of nose deformities without undue expense, anesthetic risk, or a long operation time, which are all potential shortcomings of surgical treatment [3].

Fillers can be classified according to their components (e.g., HA, collagen, paraffin, liquid silicone, and others) [6], and according to their longevity (nonpermanent, semipermanent, or permanent). In general, nonpermanent fillers consist of HA and collagen. They last for less than 1 year. Products with a duration of more than 1 year are referred to as semipermanent products, and include calcium hydroxyapatite and poly-L-lactic acid fillers. Permanent fillers, such as silicone, PMMA, and polyacrylamide hydrogel (Aquamid ${ }^{\circledR}$ ) have the longest activation time [6,7]. Importantly, the proper selection of soft-tissue fillers should be based on an understanding of their composition and properties [8].

According to previous studies, HA-based fillers have been used to augment or reshape unoperated noses [3-5], but they are considered to be temporary fillers. Additionally, the injection of hyaluronidase can reverse the effects of the filler when the position or shape of the injected filler is unsatisfactory [3]. Therefore, we excluded patients who had been initially treated with HA, since our objective was to assess the appearance of the remaining filler.

Semipermanent and permanent fillers have superior longevity, but are more palpable than HA-based fillers. Although the presence of remaining filler has been confirmed by ultrasonography 

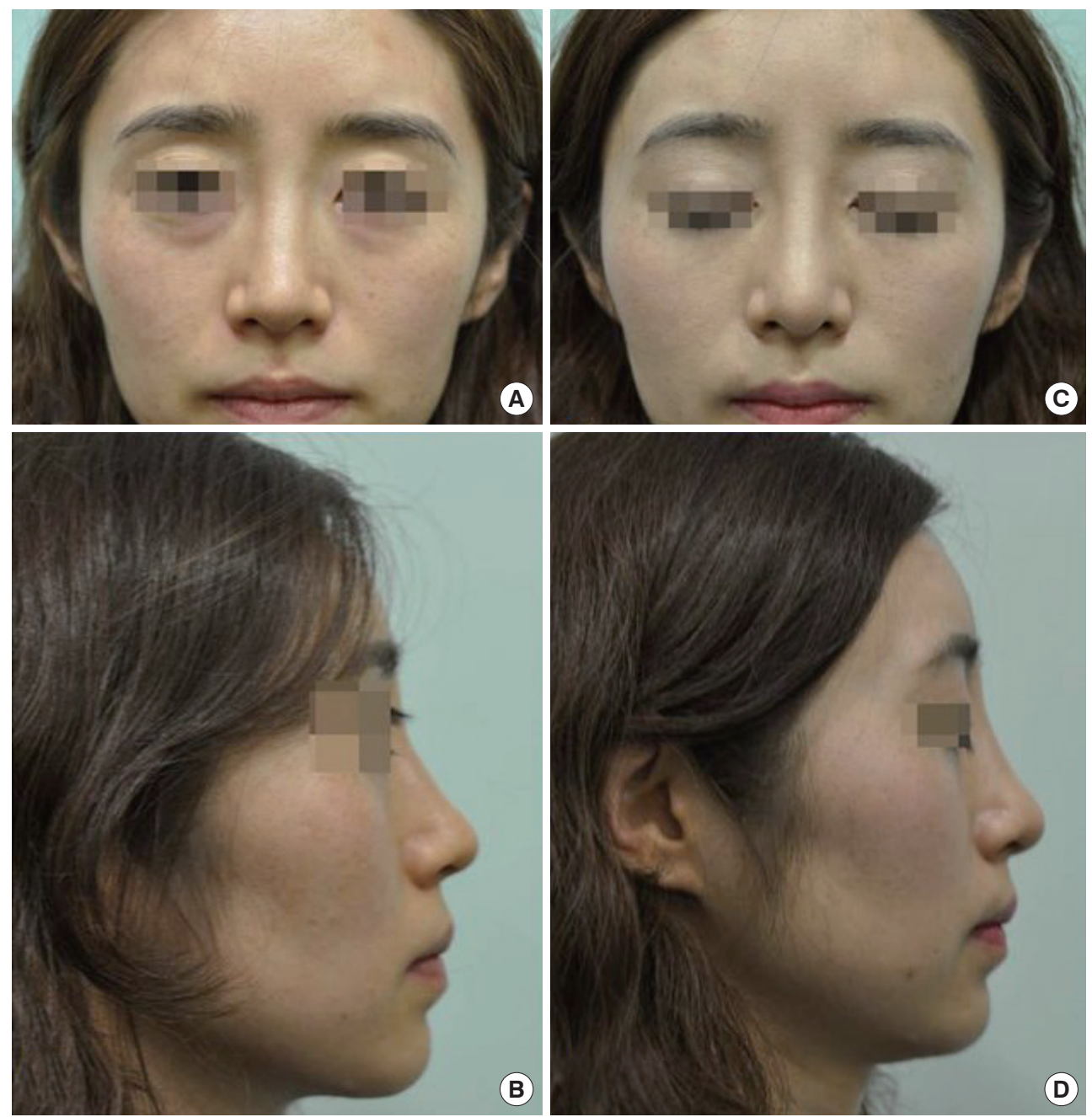

Fig. 5. A patient who received a Bio-alcamid ${ }^{\circledR}$ injection underwent secondary augmentation using Surgiform ${ }^{\circledR} 10$ months later. (A, B) Preoperative photographic findings show mild deviation on the right side. (C, D) In the postoperative photographic findings, the previously observed nasal deviation is corrected and the nasal dorsum line is elevated.

and magnetic resonance imaging $[1,9,10]$, these studies were performed when complications occurred. In the absence of complications, no case has been reported in which remaining filler was observable by the naked eye. However, in our study, patients who had previously undergone filler injections visited our hospital for reoperations not because of filler-related complications (e.g., infection, skin damage, or necrosis), but rather because they were dissatisfied with their nose shapes. Some wanted to raise their nasal dorsum and tip more. Another wanted to correct a blunt nose, and some wanted their nose to look sharp because the nose was too wide. Patients who injected semipermanent fillers visited our hospital for permanent surgery. In other words, patients enrolled in our study could be considered to have filler that had stabilized in vivo.

In this study, open rhinoplasty was performed as a secondary operation. Among the permanent fillers, Aquamid ${ }^{\circledR}$ can be removed by manual expression or needle aspiration without an open proce- dure [11]. However, all permanent fillers require a surgical procedure for removal.

In some patients with a history of permanent filler injection, the fillers were observed to be attached to the surrounding tissue in a particulate pattern. Artecoll ${ }^{\circledR}$ produced lumpy shapes, and its adhesion to the skin made it difficult to remove. Artecoll ${ }^{\circledR}$ is made from PMMA microspheres suspended in bovine collagen. After Artecoll $^{\circledR}$ is injected, bovine collagen is absorbed. PMMA is surrounded by the patient's own collagen and becomes stable. Through this principle, the effects of Artecoll ${ }^{\circledR}$ continue permanently [10]. In patients treated with Radiesse ${ }^{\circledR}$, which is known to be a semipermanent filler, the residual filler was buried in the tissue in powder form, making it difficult to remove all the material.

Although we chose secondary implants based on the patients' decisions, no major problems were encountered regarding filler residues after their removal in the secondary operation, and all cas- 
es were well managed using secondary implants without any notable complications. This may have been due to the stabilization of the surrounding tissues at the time of the second operation, despite the presence of residual filler particles. Because the surrounding tissue was stabilized when the filler was removed, it can be considered that complications did not occur, even if we proceeded in a single stage without a further interval before implant insertion.

We recommend that HA fillers be used for primary rhinoplasty because they are absorbed. We also recommend that the bolus injection method be adopted when a patient requests a licensed permanent filler, as this facilitates uncomplicated removal.

Our study has some limitations. First, the scope of this study is limited by the size of its cohort (17 cases), making our findings difficult to generalize. Second, since our study was conducted in a local clinic, histologic examinations of the removed filler and surrounding tissues were not performed. Grossly, we observed no inflammatory reactions such as induration, and the surrounding tissues were healthy. However, a histological demonstration of the stabilization of the surrounding tissue without an inflammatory reaction, despite the presence of residual filler particles, remains necessary.

\section{CONCLUSIONS}

We directly verified the presence of remnants of previously injected particulate-based fillers in secondary operations and demonstrated that if the surrounding tissue is stably maintained, secondary operations with implant insertion are successful in most cases, without complications despite the presence of residual filler remnants.

\section{PATIENT CONSENT}

Patients provided written consent for the use of their images.

\section{REFERENCES}

1. Kadouch JA, Tutein Nolthenius CJ, Kadouch DJ, et al. Complications after facial injections with permanent fillers: important limitations and considerations of MRI evaluation. Aesthet Surg J 2014;34:913-23.

2. Choi WY, Cho HW, Lee DW. Complications of injectable soft tissue filler. Arch Aesthetic Plast Surg 2015;21:1-6.

3. Humphrey CD, Arkins JP, Dayan SH. Soft tissue fillers in the nose. Aesthet Surg J 2009;29:477-84.

4. de Lacerda DA, Zancanaro P. Filler rhinoplasty. Dermatol Surg 2007;33 Suppl 2:S207-12.

5. Kim P, Ahn JT. Structured nonsurgical Asian rhinoplasty. Aesthetic Plast Surg 2012;36:698-703.

6. Moon HJ. Use of fillers in rhinoplasty. Clin Plast Surg 2016;43:307-17.

7. Yamauchi PS. Emerging permanent filler technologies: focus on Aquamid. Clin Cosmet Investig Dermatol 2014;7:261-6.

8. Sundaram H, Voigts B, Beer K, et al. Comparison of the rheological properties of viscosity and elasticity in two categories of soft tissue fillers: calcium hydroxylapatite and hyaluronic acid. Dermatol Surg 2010; 36 Suppl 3:1859-65.

9. Wortsman X, Wortsman J, Orlandi C, et al. Ultrasound detection and identification of cosmetic fillers in the skin. J Eur Acad Dermatol Venereol 2012;26:292-301.

10. Grippaudo FR, Mattei M. High-frequency sonography of temporary and permanent dermal fillers. Skin Res Technol 2010;16:265-9.

11. Wolter TP, Pallua N. Removal of the permanent filler polyacrylamide hydrogel (aquamid) is possible and easy even after several years. Plast Reconstr Surg 2010;126:138e-9e. 